\title{
KONTRADIKSI IMPLEMENTASI PASAL 79A UNDANG UNDANG NOMOR 24 TAHUN 2013 TENTANG ADMINISTRASI KEPENDUDUKAN DI KOTA DENPASAR
}

Oleh:

\author{
I Ketut Purna Astha ${ }^{1}$
}

\begin{abstract}
The problem that there is a contradiction between the article 110 (1) C Undang-Undang Republik Indonesia number 28 year 2009 which is decisive that there is a contribution in the case of reimbursement cost of printing identification cards and article $79 A$ Undang-Undang Republik Indonesia number 24 year 2013 on Residential Administration which prohibits any retribution on getting and issuing residential document. The study method employed in this study including kind of normative law study and the approach methods used are: law approach, history approach an conceptual approach. The conclusions are: considering that there a contradiction between the article 110 (1) C Undang-Undang Republik Indonesia number 28 year 2009 should not be in practiceany longer. Another conclusion is that the decree of the Majelis Madya Desa Pekraman Number : 14/12-SK/MMDP/VII/2014 in which arranged the management of incoming residents are to pay contribution when they apply for KIPS and STPPTS, is contradictory with Undang-Undang Republic Indonesia Number 24 year 2013 particularly article 79A, because the mentioned Undang-Undang is higher in position than the mentioned decree.
\end{abstract}

Keywords: council of desa pakraman, document, general services, residential, retribution,

\section{PENDAHULUAN}

\subsection{Latar Belakang Masalah}

Berdasarkan ketentuan Pasal 18 ayat

(1) dan (2) Amandemen Undang - Undang Dasar Negara Republik Indonesia 1945. Dibagi menjadi daerah-daerah provinsi, dan daerah provinsi terdiri dari daerahdaerah kabupaten. Hak ini dilakukan untuk mengupayakan pelayanan yang lebih dekat terhadap masyarakat, untuk mewujudkan tujuan negara yang tercantum dalam Pembukaan Undang-Undang Dasar Negara Republik Indonesia 1945.

Mahasiswa Magister (S2) Ilmu Hukum Universitas Udayana, Denpasar, Bali, Alamat: Perum. Padang Asri Blok 9 Nomor 39, Padangsambian, email: purnaastha@gmail.com.
Pelimpahan kewenangan pusat kepada daerah melahirkan otonomi daerah. R.G. Kartasapoetra menyatakan bahwa desentralisasi merupakan penyerahan urusan dari pemerintah pusat pada pemerintah daerah guna mengurus rumah tangganya. Dalam arti, penyerahan ini bertujuan untuk mencegah pemusatankekuasaan, keuangan serta sebagai pendemokratisasian pemerintahan, untuk mengikutsertakan rakyat bertanggung jawab terhadap penyelenggaraan pemerintahan di daerah. $^{2}$

Prinsip otonomi daerah selanjutnya dijelaskan lebih lanjut dalam Pasal 18 ayat (5) (UUDNRI) Undang - Undang Dasar Negara

Busrizalti, 2013, Hukum Pemda Otonomi Daerah Dan Implikasinya, Total Media, Yogyakarta, hlm.2. 
Republik Indonesia 1945 yang menyatakan bahwa: "Pemerintah Daerah menjalani otonomi seluas-luasnya, kecuali urusan Pemerintah yang oleh Undang-Undang ditentukan sebagai urusan pemerintah pusat". Kewenangan pemerintah daerah dalam mengurus urusan rumah tangganya menggunakan prinsip otonomi seluasluasnya, guna membuat kebijakan daerah untuk memberi pelayanan, peningkatan peran serta, prakarsa, dan pemberdayaan masyarakat yang bertujuan meningkatkan kesejahteraan masyarakat.

Prinsip otonomi seluas-luasnya diatur dalam Undang-Undang Nomor 23 Tahun 2014 tentang Pemerintahan Daerah. Dalam Pasal 1 ayat (6) ditentukan bahwa Otonomi Daerah adalah hak, wewenang dan kewajiban daerah otonom untuk mengatur dan mengurus sendiri urusan pemerintahan dan kepentingan masyarakat setempat dalam sistem Negara Kesatuan Republik Indonesia. Selanjutnya dalam Pasal 10 ayat (1) dinyatakan: Urusan pemerintahan absolut sebagaimana dimaksud dalam Pasal 9 ayat (2) meliputi politik luar negeri, pertahanan, keamanan, yustisi, moneter dan fiskal nasional, dan agama. Pembagian kewenangan antara Pemerintah Pusat dengan Pemerintah Daerah lebih lanjut diatur dalam Peraturan Pemerintah nomor 38 Tahun 2007 tentang pembagian Urusan Pemerintahan antara Pemerintah, Pemerintahan Daerah Provinsi, dan Pemerintahan Daerah Kabupaten/Kota.

Satu segi utama dalam pelaksanaan otonomi daerah adalah adanya sumber pembagian, yang dapat diandalkan untuk melaksanakan tugas pemerintahan dan pembangunan. Salah satu sumber pembagian adalah pajak dan retribusi daerah, yang dapat dikembangkan sesuai dengan potensi daerah masing-masing.
Pasal 17 (1) Undang-Undang Nomor 23 Tahun 2014 tentang Pemerintahan Daerah daerah berhak menetapkan kebijakan daerah untuk menyelenggarakan urusan pemerintahan yang menjadi kewenangan daerah termasuk pajak daerah dan retribusi daerah. Diatur berdasarkan Undang-Undang Nomor 33 Tahun 2004 tentang Perimbangan Keuangan Antara Pusat dan Daerah Pasal 1 angka 18, pendapatan asli daerah berarti, "Pendapatan asli daerah, selanjutnya disebut PAD adalah pendapatan yang diperoleh daerah yang dipungut berdasarkan peraturan daerah sesuai dengan peraturan perundangundangan."

Dalam ketentuan Pasal 285 UndangUndang Nomor 23 Tahun 2014 ditentukan Pendapat Asli Daerah (PAD) yaitu:
1) pajak daerah
2) retribusi daerah
3) Hasil pengelolaan kekayaan daerah yang dipisahkan
4) Lain-lain pendapat daerah yang sah Pendapatan asli daerah yang bersumber dari pungutan pada masyarakat, yaitu:

(1) Retribusi yang dipungut dengan kompensasi layanan tertentu; dan

(2) Pajak yang dipungut tanpa kompensasi layanan. ${ }^{3}$

Pajak adalah pungutan oleh pejabat pajak sebagai wakil Negara kepada wajib pajak tanpa tegenprestasi secara langsung dan bersifat memaksa sehingga penagihannya dapat dipaksakan. Hal ini tersirat dalam Pasal 23A Undang-Undang Dasar Negara Republik Indonesia 1945.

Wahyudi Kumorotomo, 2006, Desentralisasi fiskal : Politik Perubahan Kebijakan 1974-2004, Kencana, Jakarta, hlm.125. 
Pajak daerah didalamnya harus pula terdapat unsur imbalan / kontraprestasi sebagaimana halnya retribusi daerah. Yang membedakan imbalan / kontraprestasi keduanya adalah bahwa pajak daerah kontraprestasi tersebut untuk masyarakat yang lebih luas, atau setidak-tidaknya untuk sektor pajak yang bersangkutan, sedangkan kontraprestasi langsung kepada pembayar retribusi. ${ }^{4}$

Retribusi adalah pungutan oleh pejabat retribusi kepada Wajib Retribusi yang bersifat memaksa dengan tegenprestatie secara langsung dan dapat dipaksakan penagihannya. Saranahukumyang digunakan untuk memaksakan penagihan retribusi tidak berbeda dengan pajak, berupa sanksi administrasi maupun sanksi kepidanaan. ${ }^{5}$ Retribusi dalam Pasal 23A UndangUndang Dasar 1945 merupakan bagian dari "pungutan yang bersifat memaksa" yang dibutuhkan oleh Negara karena itu diatur dengan undang-undang ${ }^{6}$.

Menurut Pasal 23A Undang-Undang Dasar Negara Republik Indonesia Tahun 1945 yang menentukan:

"Pajak dan pungutan lain yang bersifat memaksa untuk keperluan Negara diatur dengan undang-undang”.

Dalam Pasal 1 angka 64 UndangUndang Nomor 28 Tahun 2009 tentang Pajak Daerah dan Retribusi Daerah ditentukan:

"Retribusi daerah, yang selanjutnya disebut retribusi, adalah pungutan Daerah sebagai pembayaran atas jasa atau pemberian

Tjip Ismail, 2007, Pengaturan Pajak Daerah di Indonesia, Yellow Printing, Jakarta, hlm.56.

Muhammad Djafar Saidi, 2007, Pembaruan Hukum Pajak, PT. Raja Grafindo Persada, Jakarta, hlm.2526.

$6 \quad$ Ibid ijin tertentu yang khusus disediakan dan/ atau diberikan oleh Pemerintah Daerah untuk kepentingan orang pribadi atau badan."

Pasal 108 ayat (1) Undang Undang Nomor 28 Tahun 2009 tentang Pajak Daerah dan Retribusi Daerah menentukan bahwa "Objek retribusi” adalah:

a. Jasa umum;

b. Jasa usaha;

c. Perizinan tertentu.

Objek retribusi oleh Pemerintah

Daerah tersebut dikelompokkan kedalam 3 (tiga) golongan, yaitu jasa umum, jasa usaha, dan perizinan tertentu, yaitu ${ }^{7}$ :

1. Retribusi jasa umum, adalah retribusi atas jasa yang disediakan atau diberikan oleh pemerintah daerah untuk tujuan kepentingan dan kemanfaatan umum serta dapat dinikmati oleh pribadi atau badan.

2. Retribusijasausahaadalahretribusiatas jasa yang diberikan oleh pemerintah daerah dengan menganut prinsip komersial karena pada dasarnya dapat pula disediakan oleh sektor swasta.

3. Retribusi perijinan tertentu adalah retribusi atas kegiatan tertentu pemerintah daerah dalam rangka pemberian ijin kepada orang pribadi atau badan yang dimaksudkan untuk pembinaan, pengaturan, pengendalian dan pengawasan atas kegiatan kemanfaatan pemanfaatan ruang, penggunaan sumber daya alam, barang, prasarana, sarana atau fasilitas tertentu guna melindungi kepentingan umum dan menjaga kelestarian lingkungan.

Dalam implementasi otonomi daerah,

Siahaan P. Marihot, 2009, Pajak Daerah dan Retribusi Daerah, PT. Raja Grafindo Persada, Jakarta, hlm..435. 
kewenangan dalam melaksakana pungutan pajak daerah dan retribusi daerah ini diatur dalam Pasal 79A Undang-Undang Nomor 24 Tahun 2013 tentang Administrasi Kependudukan yaitu "Pengurusan dan Penerbitan Dokumen Kependudukan tidak dipungut biaya", disisi lain dalam Pasal 110 ayat (1) huruf C Undang Undang Nomor 28 Tahun 2009 bahwa Retribusi Penggantian Biaya Cetak Kartu Tanda Penduduk dan Akta Catatan Sipil digolongkan dalam Retribusi Jasa Umum yang mana merupakan pungutan daerah sebagai pembayaran atas jasa yang disediakan dan atau diberikan oleh pemerintah daerah untuk kepentingan orang pribadi / Badan.

Atas dasar permasalahan itulah maka penulis menganggap perlu untuk melakukan suatu kajian ilmiah denganjudul "Kontradiksi Implementasi Pasal 79A Undang Undang Nomor 24 Tahun 2013 Tentang Administrasi Kependudukan Di Kota Denpasar"

\subsection{Rumusan Masalah}

Bertitik tolak dari latar belakang masalah tersebut diatas, dapat dirumuskan permasalahan sebagai berikut:

1. Bagaimanakah konsistensi antara Pasal 79A Undang-Undang Nomor 24 Tahun 2013 tentang Administrasi Kependudukan dengan Pasal 110 ayat (1) huruf C Undang - Undang Nomor 28 Tahun 2009 tentang Pajak Daerah dan Retribusi Daerah?

2. Bagaimana konsistensi antara

Keputusan Majelis Madya Desa

Pakraman Kota Denpasar Nomor 14/12-SK/MMDP/VII/2014 dengan pasal 79A Undang-Undang Nomor 24 Tahun 2013 tentang Administrasi Kependudukan?

\subsection{Tujuan Penelitian}

Pelaksanaan penelitian ini bertujuan sebagai berikut:

a. Menganalisis inkonsistensi antara peraturan tentang retribusi jasa umum kependudukan terhadap Pasal 79A Undang-Undang Nomor24Tahun 2013 Tentang Administrasi Kependudukan.

b. Untuk Menganalisis inkonsistensi Majelis Madya Desa Pakraman dalam pemungutan retribusi jasa umum kependudukan di Kota Denpasar

\section{METODE PENELITIAN}

\subsection{Jenis Penelitian}

Penelitian ini menggunakan metode penelitian hukum normatif. Metode penelitian normatif adalah "suatu prosedur penelitian ilmiah untuk menemukan kebenaran berdasarkan logika keilmuan hukum dari sisi normatifnya." Dalam khasanah penelitian hukum, penelitian yang dilakukan .dengan mengkaji bahan pustaka atau disebut juga studi kepustakaan. Penelitian ini dilakukan dengan mengkaji dan menganalisis bahan hukum berupa bahan-bahan yang terkait hukum primer, sekunder maupun tertier dengan retribusi jasa umum.

\subsection{Jenis Pendekatan}

Didalam penelitian ini, digunakan pendekatan perundang-undangan (statute approach) dan pendekatan konseptual (conceptual approach). Pendekatan perundang-undangan (Statute Approach) digunakan sebagai perangkat guna menganalisis berbagai peraturan perundang-

Johnny Ibrahim, 2007, Teori dan Metodologi Penelitian Hukum Normatif, Bayumedia Publising, Malang, hlm.57. 
undangan mengenai retribusi jasa umum. Pendekatan perundang-undangan dilakukan dengan maksud untuk mengetahui makna yang terkandung dalam peraturan perundang-undangan dengan permasalahan dalam penelitian ini. Pendekatan Konseptual (conceptual approach) dilakukan dengan cara menganalisis berbagai konsep dan pengertian tentang retribusi jasa umum.

\subsection{Sumber Bahan Hukum}

Penelitian ini menitikberatkan pada penelitian kepustakaan (library research) dengan menggunakan data sekunder bahan kepustakaan. Adapun bahan hukum yang akan dijadikan sumberpenelitian kepustakaan ini dalam sudut kekuatan mengikatnya digolongkan menjadi tiga yaitu:

a. Bahan hukum primer, adalah bahan hukum yang mengikat.

b. Bahan hukum sekunder, yang memberikan penjelasan mengenai bahan hukum primer, yang meliputi hasil-hasil penelitian, buku-buku, dokumen-dokumen yang diperoleh dari Dinas Kependudukan dan Catatan Sipil Kota Denpasar.

c. Bahan hukum tertier, yakni bahan hukum yang memberikan petunjuk maupun penjelasan terhadap bahan hukum sekunder, yang seperti:

1. Kamus hukum

\subsection{Teknik Pengumpulan Hukum}

Mengenai teknik yang diterapkan dalam pengumpulan bahan hukum dalam penelitian dini dilakukan melalui teknik telaahan kepustakaan (study document). Telaahan kepustakaan dilakukan dengan system kartu (cardsystem) yakni dengan mencatat dan memahami isi dari masingmasing informasi yang diperoleh dari bahan primer, sekunder dan tertier.

Bahan hukum sekunder diperoleh dari kepustakaan dan penelitian kasus dimana penelitian kasus berguna dalam memberikan latar belakang yang lebih luas mengenai pokok penelitian serta memberikan penjelasan yang lebih konkrit berkaitan dengan permasalahan yang ada.

\subsection{Teknik Analisis}

Bahan-bahan hukum yang sudah dikumpulkan, selanjutnya dianalisis dengan tahapan teknis analisis sebagai berikut: Tahapan pendeskripsian atau penggambaran yaitu dengan menguraikan proposisiproposisi hukum sesuai pokok permasalahan yang dikaji untuk selanjutnya dilakukan interpretasi. Untuk selanjutnya dilakukan tahap sistematisasi yaitu dengan mencari kaitan suatu konsep hukum atau proposisi hukum antara perundang-undangan yang sederajat maupun yang tidak sederajat. Dan tahapan yang terakhir adalah Evaluasi atau analisis yaitu dengan memberi penilaian, antara lain sah atau tidak sah, benar atau salah, setuju atau tidak setuju, tepat atau tidak tepat oleh peneliti terhadap suatu pernyataan, proposisi, pandangan, rumusan norma, atau keputusan yang tertera dalam bahan hukum primer dan bahan hukum sekunder. Hasil penerapan dari keempat tahapan tersebut kemudian diberikan argumentasi hukum untuk mendapatkan kesimpulan atas permasalahan yang akan dibahas dalam kajian ini. 
III. HASIL DAN PEMBAHASAN

3.1. Konsistensi Pasal 79A UndangUndang Nomor 24 Tahun 2013 Tentang Administrasi

Kependudukan Dikaitkan Dengan Pasal 110 Ayat (1) huruf C Undang-Undang Nomor 28 tahun 2009 Tentang Pajak Daerah Dan Retribusi Daerah.

Dalam Pasal 1 angka 64 UndangUndang Nomor 28 Tahun 2009 tentang Pajak Daerah dan Retribusi Daerah ditentukan:

"Retribusi daerah, yang selanjutnya disebut retribusi, adalah pungutan Daerah sebagai pembayaran atas jasa atau pemberian ijin tertentu yang khusus disediakan dan/ atau diberikan oleh Pemerintah Daerah untuk kepentingan orang pribadi atau badan."

Dalam pengertian ini, terkandung pula pemaknaan bahwa pelayanan yang menjadi obyek retribusi adalah pelayanan yang langsung dinikmati oleh anggota masyarakat (orang pribadi atau badan). Dengan demikian karakter retribusi daerah adalah :

1. Pungutan oleh pemerintah daerah terhadap anggota masyarakat;

2. Pemerintah daerah memberikan pelayanan berupa barang/jasa yang memberi keuntungan kepada anggota masyarakat yang membayar pungutan. Pasal 108 ayat (1) Undang Undang Nomor 28 Tahun 2009 tentang Pajak Daerah dan Retribusi Daerah menentukan bahwa "Objek retribusi adalah " :
d. Jasa umum;
e. Jasa usaha;
f. Perizinan tertentu.

Dalam melaksanakan pungutan retribusi, tidak seluruh jasa yang disediakan pemerintah daerah masuk dalam kategori objek retribusi. Objek retribusi oleh Pemerintah Daerah tersebut dikelompokkan kedalam 3 (tiga) golongan jasa, ${ }^{9}$ yaitu:

1. Retribusi jasa umum, adalah retribusi atas jasa yang disediakan atau diberikan oleh pemerintah daerah untuk tujuan kepentingan dan kemanfaatan umum serta dapat dinikmati oleh pribadi atau badan.

2. Retribusijasausahaadalahretribusiatas jasa yang diberikan oleh pemerintah daerah dengan menganut prinsip komersial karena pada dasarnya dapat pula disediakan oleh sektor swasta.

3. Retribusi perijinan tertentu adalah retribusi atas kegiatan tertentu pemerintah daerah dalam rangka pemberian ijin kepada orang pribadi atau badan yang dimaksudkan untuk pembinaan, pengaturan, pengendalian dan pengawasan atas kegiatan kemanfaatan pemanfaatan ruang, penggunaan sumber daya alam, barang, prasarana, sarana atau fasilitas tertentu guna melindungi kepentingan umum dan menjaga kelestarian lingkungan.

Lebih lanjut dalam Pasal 110 ayat 1 Undang Undang Nomor 28 Tahun 2009 tentang Pajak Daerah dan Retribusi Daerah menentukan bahwa Jenis Retribusi Jasa Umum adalah:

a. Retribusi Pelayanan Kesehatan

b. Retribusi Pelayanan Persampahan/ Kebersihan 
c. Retribusi Penggantian Biaya Cetak Kartu Tanda Penduduk dan Akta Catatan Sipil

d. Retribusi Pelayanan Pemakaman dan Pengabuan Mayat

e. Retribusi Pelayanan Parkir di Tepi Jalan Umum

f. Retribusi Pelayanan Pasar

g. Retribusi Pengujian Kendaraan Bermotor

h. Retribusi Pemeriksaan Alat Pemadam Kebakaran

i. Retribusi Penggantian Biaya Cetak Peta

j. Retribusi Penyediaan dan/atau Penyedotan Kakus

k. Retribusi Pengolahan Limbah Cair

1. Retribusi Pelayanan Tera/Tera Ulang

m. Retribusi Pelayanan Pendidikan

n. Retribusi Pengendalian Menara Telekomunikasi

Pasal 156 ayat (1) Undang-Undang Nomor 28 Tahun 2009 tentang Pajak Daerah dan Retribusi Daerah menyatakan: "Retribusi ditetapkan dengan Peraturan Daerah".

Dalam Pasal 110 ayat (1) huruf C Undang Undang Nomor 28 Tahun 2009 ditentukan bahwa Retribusi Penggantian Biaya Cetak Kartu Tanda Penduduk dan Akta Catatan Sipil digolongkan dalam Retribusi Jasa Umum yang mana merupakan pungutan daerah sebagai pembayaran atas jasa yang disediakan dan atau diberikan oleh pemerintah daerah untuk kepentingan orang pribadi / Badan.

Sedangkan dalam Pasal 79A UndangUndang Nomor 24 Tahun 2013 tentang Administrasi Kependudukan ditentukan "Pengurusan dan Penerbitan Dokumen Kependudukan tidak dipungut biaya".
Dalam hal ini ada ketidaksesuaian atau inkonsistensi antara Pasal 110 ayat (1) huruf C Undang Undang Nomor 28 Tahun 2009 dengan pasal 79A Undang-Undang Republik Indonesia Nomor 24 Tahun 2013. Berdasarkan teori Antinomi dimana adanya pertentangan dua nilai atau lebih, akan tetapi keduanya sama-sama penting atau dalam tingkatan hukum yang sama maka asas preferensi dalam penyelesaian konflik norma tersebut yaitu Asas Lex Specialis Derogat Legi Generali, yaitu peraturan perundang-undangan yang bersifat khusus (special) mengenyampingkan berlakunya peraturan perundang-undangan yang bersifat umum (general), apabila kedua peraturan perundang-undangan tersebut memuat ketentuan yang saling bertentangan. Asas ini merujuk kepada dua peraturan perundangundangan yang secara hierarkis mempunyai kedudukan yang sama. ${ }^{10}$

Berdasarkan asas tersebut maka yang berlaku adalah pasal 79A Undang-Undang Republik Indonesia Nomor 24 Tahun 2013 tentang Administrasi Kependudukan ditentukan "Pengurusan dan Penerbitan Dokumen Kependudukan tidak dipungut biaya".

3.2. Konsistensi antara Keputusan Majelis Madya Desa Pakraman Kota Denpasar Nomor 14/12-SK/ MMDP/VII/2014 dengan pasal 79A Undang-Undang Nomor 24 Tahun 2013 tentang Administrasi Kependudukan

Pada tingkat Desa Pakraman kepengurusan KIPPS (Kartu Identitas

0 Peter Mahmud Marzuki, 2013, Penelitian Hukum, Raja Grafindo Persada, Jakarta, hlm.129. 
Penduduk Pendatang Sementara dan STPPTS (Surat Tanda Penduduk Pendatang Tinggal Sementara) dipungut kontribusi biaya berdasarkan Keputusan Majelis Madya Desa Pakraman Kota Denpasar Nomor 14/12-SK/MMDP/VII/2014 tertanggal 1 Juli 2014 tentang Penataan Penduduk Pendatang Di Desa Pakraman. KIPPS (Kartu Identitas Penduduk Pendatang Sementara dan STPPTS (Surat Tanda Penduduk Pendatang Tinggal Sementara) merupakan salah satu dokumen kependudukan berdasarkan pasal 1 poin 8 Undang-Undang nomor 24 Tahun 2013 disebutkan Dokumen kependudukan adalah dokumen resmi yang diterbitkan oleh Instansi Pelaksana yang mempunyai kekuatan hukum sebagai alat bukti otentik yang dihasilkan dari pelayanan Pendaftaran penduduk dan Pencatatan sipil dan berdasarkan Pasal 113 Undang-Undang Nomor 28 tahun 2009 disebutkan objek retribusi penggantian biaya cetak Kartu Tanda Penduduk dan Catatan sipil sebagaimana dimaksud dalam pasal 110 ayat (1) huruf $\mathrm{c}$ adalah pelayanan :
a. Kartu tanda penduduk;
b. Kartu keterangan bertempat tinggal;
c. Kartu identitas kerja;
d. Kartu penduduk sementara;
e. Kartu identitas penduduk musiman;
f. Kartu Keluarga;
g. Akta catatan sipil yang meliputi akta perkawinan, akta perceraian, akta pengesahan dan pengakuan anak, akta ganti nama bagi warga Negara asing, dan akta kematian.

Dalam Keputusan tersebut ditentukan untuk menjamin ketertiban dan keamanan sosial dalam penataan penduduk pendatang (krama tamiu dan tamiu) yang baru datang dan tinggal menetap maupun sementara dalam jangka waktu tertentu, dikenakan kontribusi biaya sebesar Rp. 100.000,00 (seratus ribu rupiah) bagi penduduk pendatang luar Provinsi Bali dan penduduk pendatang luar Denpasar dalam Provinsi Bali sebesar Rp. 25.000,00 (dua puluh lima ribu rupiah). Pengenaan dan penggunaan kontribusi biaya tersebut diatur oleh masingmasing Desa Pakraman dan dikoordinasikan kepada Desa dan Kelurahan sebagai wujud sinergi dan koordinasi dalam pengendalian kependudukan." 11

Berdasarkan teori pluralisme hukum maka dalam hal ini terjadi pluralisme hukum lemah (weak pluralism) adalah merupakan bentuk lain dari sentralisme hukum dimana Negara (dan pemerintah) mengakui hadirnya sistem-sistem hukum lain dalam hal ini hukum lokal (folklaw) di luar hukum Negara tetapi sistem-sistem hukum non-negara tersebut tunduk keberlakuannya di bawah hukum Negara atau dengan kata lain selain pengakuan terhadap adanya pluralisme hukum (sistem hukum adat) dan di sisi lain pengakuan terhadap hukum Negara dipandang tetap sebagai hukum yang lebih kuat (superior).

Berlakunya Surat Keputusan tersebut di samping Surat Edaran Menteri Dalam Negeri berdasarkan teori the semiautonomous social field oleh Sally Falk Moore memberikan penekanan pada otonomi yang sebagian atau semi-otonom. Semi otonom merupakan suatu fakta bahwa bidang yang kecil dapat menghasilkan aturan-aturan dan adat kebiasaan. Bagi Sally Folk Moore seluruh aneka norma dan aturan yang muncul dari individu ataupun masyarakat tertentu dapat berfungsi sebagai hukum. Kapasitas kelompok-kelompok sosial (socialfield)

Keputusan Majelis Madya Desa Pakraman Kota Denpasar, Nomor 14/12-SK/MMDP/VII/2014. 
dalam menciptakan mekanisme-mekanisme pengaturan sendiri (self-regulation) dengan disertai kekuatan-kekuatan pemaksa. "Bidang yang kecil dan untuk sebagian otonomi itu dapat menghasilkan aturanaturan dan adat istiadat serta simbol-simbol berasal dari dalam. Di lain pihak, bidang tersebut juga rentan terhadap aturan-aturan, keputusan-keputusan dan kekuatan-kekuatan lain yang berasal dari dunia luar yang mengelilinginya." 12

Menurut Moore kondisi pluralistik di bidang hukum ini dengan mengamati bidangbidang sosial dalam hal ini kependudukan yang terdapat dalam masyarakat. Dalam bidang sosial ini masyarakat dapat membuat aturannya sendiri melalui keputusan bersama ataupun melalui keputusan dari individu atau kelompok yang diberi otoritas untuk itu. Aturan tersebut bersifat mengikat, pelanggaran terhadap aturan yang dibuat akan menghasilkan sanksi yang biasanya bersifat sosial. Bidang-bidang sosial ini meskipun nampaknya memiliki otoritas untuk menghasilkan aturan, ternyata tetap bersifat rentan terhadap aturan lain yang berasal dari luar yang dimaksud adalah Negara, adat maupun agama.

Lebih lanjut Hooker menyatakan "The term pluralism refers to the situations in which two or more laws interact". Pernyataan ini mempunyai makna bahwa meskipun mengakui adanya berbagai jenis sistem hukum namun tetap menekankan bahwa adanya pertentangan antara sistem hukum yang dominan atau superior (Negara) dengan sistem hukum yang inferior (hukum adat).

12 Sally Falk Moore, 2001, "Hukum dan Perubahan Sosial: Bidang Sosial Semi-Otonom sebagai suatu Topik Studi yang Tepat”. Dalam T.O. Ihromi (Ed), Antropologi Hukum. Sebuah Bunga Rampai, Yayasan Obor, Jakarta, hlm.150.
Pertimbangan dikeluarkan Surat Keputusan tersebut berdasarkan Peraturan Daerah Provinsi Bali Nomor 3 Tahun 2003 Tentang Perubahan Kedua Atas Peraturan Daerah Propinsi Bali Nomor 3 Tahun 2001 tentang Desa Pakraman bahwa Majelis Madya Desa Pakraman Kota Denpasar sebagai lembaga adat yang menjadi partnership kerja Pemerintah Kota Denpasar berwenang membuat aturan terkait urusan pemerintahan dan urusan adat yang ditujukan dan dikoordinasikan pelaksanaannya kepada Desa Pakraman se Kota Denpasar. Hal ini tidak sesuai dengan tugas dan wewenang Majelis Desa Pakraman yang diatur dalam Pasal 16 Perda No 3 Tahun 2001 yaitu (1) Majelis Desa Pakraman mempunyai tugas: a) mengayomi adat istiadat; b) memberikan saran, usul, dan pendapat kepada berbagai pihak baik perorangan, kelompok/lembaga termasuk pemerintah tentang masalahmasalah adat; c) melaksanakan setiap keputusan-keputusan paruman dengan aturan-aturan yang ditetapkan; d) membantu penyuratan awig-awig; e) melaksanakan penyuluhan adat istiadat secara menyeluruh. (2) Majelis Desa Pakraman mempunyai wewenang: a) memusyawarahkan berbagai hal menyangkut masalah-masalah adat dan agama untuk kepentingan desa pakraman; b) sebagai penangah dalam kasus-kasus adat yang tidak dapat diselesaikan di tingkat desa; c) membantu penyelenggaraan upacara keagamaan di kecamatan, di kabupatan/kota, dan di provinsi.

Dengan adanya Surat Keputusan tersebut juga menunjukkan bahwa, Majelis Madya Desa Pakraman Kota Denpasar sebagai lembaga adat yang menjadi partnership kerja Pemerintah Kota Denpasar tidak mengikuti aturan yang ada diatasnya 
yaitu Surat Edaran Menteri Dalam Negeri Nomor 900/326/SJ tertanggal 17 Januari 2014, yang memuat per tanggal 1 April 2014 semua pelayanan adminstrasi dan penertiban dokumen kependudukan tidak dipungut biaya dan aturan lainnya yaitu pasal 79A Undang-Undang Republik Indonesia Nomor 24 Tahun 2013 tentang Perubahan Undang-Undang nomor 23 Tahun 2006 tentang Administrasi Kependudukan yang menentukan:

"Pengurusan dan penerbitan dokumen kependudukan tidak dipungut biaya".

Dalam hal ini Keputusan Majelis Madya Desa Pakraman Kota Denpasar Nomor 14/12-SK/MMDP/VII/2014 tidak konsisten dengan pasal 79A UndangUndang Nomor 24 Tahun 2013 tentang Administrasi Kependudukan yang lebih tinggi kedudukannya.

Berdasarkan teori hirarki norma hukum, norma yang berlaku dibawah harus mengacu pada norma yang diatasnya. Akan tetapi, Surat Keputusan Majelis Madya Desa Pakraman Nomor 14/12-SK/MMDP/ VII/2014 tertanggal 1 juli 2014 telah menyimpang dari Surat Edaran Menteri Dalam Negeri Nomor 900/326/SJ tertanggal 17 Januari 2014 pasal 79A Undang-Undang Republik Indonesia Nomor 24 Tahun 2013. Berdasarkan teori hierarki norma hukum segala peraturan yang berada di lapis bawah, tidak dipekenankan untuk "keluar jalur" harus sesuai dengan norma yang ada di atasnya dan norma dasar yang ada di puncak hirarki tersebut.

Lebih lanjut menurut Leopold Pospisil mengemukakan atribut yang dapat membedakan antara aktivitas hukum dan non hukum dalam masyarakat. Keempat atribut hukum tersebut adalah attribute of authority, attribute of intention of universal application, attribute of obligation, attribute of sanction. ${ }^{13}$ Berdasarkan teori di atas maka Surat Keputusan Majelis Madya Desa Pakraman Nomor 14/12-SK/MMDP/ VII/2014 merupakan produk hukum karena adanya atribut otoritas dimana Surat Keputusan Majelis Madya Desa Pakraman tersebut dihasilkan oleh sekelompok orang dalam masyarakat yang berwenang/ditunjuk untuk itu. Atribut kedua, yaitu atribut universalitas, dimana Surat Keputusan Majelis Madya Desa Pakraman berlaku secara universal. Atribut ketiga adalah obligation dimana Surat Keputusan Majelis Madya Desa Pakraman mengatur masalah hak dan kewajiban dari anggota masyarakat secara timbal balik. Atribut keempat yaitu mekanisme pemaksa berupa sanksi.

Setiap orang termasuk warga Desa Pakraman di samping harus taat pada hukum adat, juga hukum Negara, dan juga hukum agamanya, demikian menurut teori keanekaragaman system hukum (Theory of multiplicity legal system) dari Leopold Pospisil, disebutkan setiap orang selalu terikat pada berbagai system hukum, oleh karena ia terlibat lebih dari satu lingkungan masyarakat hukum. ${ }^{14}$

Hukum adat sebagai hukum "lapisan bawah" sudah tentu harus menyesuaikan diri pada hukum hukum "lapisan atas" yakni hukum Negara dan hukum agama. Terhadap hukum Negara, maka hukum adat sebagai

Lidwina Inge Nurtjahyo, "Menelusuri Perkembangan Kajian Pluralisme Hukum Di Indonesia" Dalam Myrna A. Safitri Untuk Apa Pluralisme Hukum?

Regulasi, Negosiasi, dan Perlawanan dalam Konflik Agraria di Indonesia, 2011, Epistema Institute, Jakarta, hlm.67.

14 I Made Suasthawa Dharmayuda, 2001, Desa Adat Kesatuan Masyarakat Hukum Adat di Propinsi Bali, Upada Sastra, Denpasar, hlm.54. 
hukumtingkatbawahtidakbolehbertentangan dengan hukum di atasnya. Jadi dalam hal ini terdapat pertentangan atau inkonsistensi antara Surat Keputusan Majelis Madya Desa Pakraman Nomor 14/12-SK/MMDP/ VII/2014 dengan pasal 79A Undang-Undang Republik Indonesia Nomor 24 Tahun 2013, sehingga berdasarkan asas preferensi berlaku asas Lex Superior derogate Legi Inferiori, yang maksudnya ketentuan hukum yang lebih tinggi tingkatannya dalam hal ini pasal 79A Undang-Undang Republik Indonesia Nomor 24 Tahun 2013 mengesampingkan yang lebih rendah (Surat Keputusan Majelis Madya Desa Pakraman Nomor 14/12-SK/ MMDP/VII/2014).

Di samping itu pula Desa Pakraman sebagai lembaga umat Hindu fungsi utamanya adalah mengurusi hal-hal yang menyangkut aspek keumatan dan keagamaan Hindu. Hal inilah yang menjadi tanggung jawab utama dari Desa Pakraman. Selain fungsi tersebut Desa Pakraman juga ikut serta untuk mensukseskan pembangunan di segala bidang dalam kerjasama yang bersifat holistik dan sinergis akan tetapi tetap harus berpegang pada fungsi utamanya.

Tentu hal seperti ini tidak dibenarkan dan sangat membutuhkan perhatian Pemerintah Pusat maupun Pemerintah Daerah untuk mengkaji ulang norma-norma yang berkaitan dengan retribusi jasa umum khususnya tentang dokumen kependudukan yang telah dikeluarkan oleh Majelis Madya Desa Pakraman (MMDP) Denpasar.

\section{PENUTUP}

\subsection{Simpulan}

Berdasarkan uraian dalan Bab Pembahasan di atas, peneliti dapat menyimpulkan, yaitu:
1. Adanya ketidaksesuaian atau inkonsistensi antara Pasal 110 ayat (1) huruf C Undang Undang Nomor 28 Tahun 2009 dengan pasal 79A Undang-Undang Republik Indonesia Nomor 24 Tahun 2013. Berdasarkan teori Antinomi yaitu ada pertentangan dua nilai atau lebih, tetapi keduanya sama-sama penting atau dalam tingkatan hukum yang sama maka asas preferensi dalam penyelesaian konflik norma tersebut yaitu Asas Lex Specialis Derogat Legi Generali, yaitu peraturan perundang-undangan yang bersifat khusus (special) mengenyampingkan berlakunya peraturan perundang-undangan yang bersifat umum (general), apabila kedua peraturan perundang-undangan tersebut memuat ketentuan yang saling bertentangan. Asas ini merujuk kepada dua peraturan perundang-undangan yang secara hierarkis mempunyai kedudukan yang sama. Berdasarkan asas tersebut maka yang berlaku adalah pasal 79A Undang-Undang Republik Indonesia Nomor 24 Tahun 2013 tentang Administrasi Kependudukan ditentukan "Pengurusan dan Penerbitan Dokumen Kependudukan tidak dipungut biaya”.

2. Terdapat pertentangan atau inkonsistensi antara Surat Keputusan Majelis Madya Desa Pakraman Nomor 14/12-SK/MMDP/VII/2014 dengan pasal 79A Undang-Undang Republik Indonesia Nomor 24 Tahun 2013, sehingga berdasarkan asas preferensi berlaku asas Lex Superior derogate Legi Inferiori, yang maksudnya ketentuan hukum yang lebih tinggi tingkatannya 
dalam hal ini pasal 79A UndangUndang Republik Indonesia Nomor 24 Tahun 2013 mengesampingkan yang lebih rendah (Surat Keputusan Majelis Madya Desa Pakraman Nomor 14/12SK/MMDP/VII/2014). Desa Pakraman sebagai lembaga umat Hindu fungsi utamanya adalah mengurusi hal-hal yang menyangkut aspek keumatan dan keagamaan Hindu. Hal inilah yang menjadi tanggung jawab utama dari Desa Pakraman. Selain fungsi tersebut Desa Pakraman juga ikut serta untuk mensukseskan pembangunan di segala bidang dalam kerjasama yang bersifat holistik dan sinergis akan tetapi tetap harus berpegang pada fungsi utamanya.

\subsection{Saran}

Berdasarkan simpulan di atas maka dapat disarankan:

1. Pasal 110 ayat (1) huruf C Undang Undang Nomor 28 Tahun 2009 tentang Pajak Daerah dan Retribusi Daerah yang menentukan bahwa Retribusi Penggantian Biaya Cetak Kartu Tanda Penduduk dan Akta Catatan Sipil digolongkan dalam Retribusi Jasa Umum hendaknya dicabut karena tidak sesuai dengan Undang-Undang yang lebih khusus yaitu Pasal 79A UndangUndang Nomor 24 Tahun 2013 tentang Administrasi Kependudukan.

2. Surat Keputusan Majelis Madya Desa Pakraman Nomor 14/12-SK/MMDP/ VII/2014 hendaknya dicabut dan dinyatakan tidak berlaku lagi karena bertentangan dengan aturan di atasnya. Majelis Desa Pakraman hendaknya lebih menitikberatkan dengan mengurusi hal-hal yang menyangkut aspek keumatan dan keagamaan Hindu sesuai dengan fungsi utamanya.

\section{DAFTAR PUSTAKA}

Busrizalti, 2013, Hukum Pemda Otonomi Daerah Dan Implikasinya, Total Media, Yogyakarta.

Dharmayuda, I Made Suasthawa, 2001, Desa Adat Kesatuan Masyarakat Hukum Adat di Provinsi Bali, Upada Sastra, Denpasar.

Ibrahim, Johnny, 2007, Teori dan Metodologi Penelitian Hukum Normatif, Bayumedia Publising, Malang.

Ismail, Tjip, 2007, Pengaturan Pajak Daerah di Indonesia, Yellow Printing, Jakarta.

Kumorotomo, Wahyudi 2006, Desentralisasi Fiskal: Politik Perubahan Kebijakan 1974-2004, Kencana, Jakarta.

Marihot, Siahaan P., 2009, Pajak Daerah Dan Retribusi Daerah, PT. Raja Grafindo Persada, Jakarta.

Marzuki, Peter Mahmud, 2013, Penelitian Hukum, Raja Grafindo Persada, Jakarta.

Moore, Sally Falk, 2001, "Hukum dan Perubahan Sosial: Bidang Sosial Semi-Otonom sebagai suatu Topik Studi yang Tepat". dalam: T.O. Ihromi (Ed), Antropologi Hukum. Sebuah Bunga Rampai, Yayasan Obor, Jakarta.

Nurtjahyo, Lidwina Inge, "Menelusuri Perkembangan Kajian Pluralisme Hukum Di Indonesia" Dalam Myrna A. Safitri Untuk Apa Pluralisme Hukum? Regulasi, Negosiasi, dan Perlawanan dalam Konflik Agraria di Indonesia, 2011, Epistema Institute, Jakarta. 
Saidi, Muhammad Djafar, 2007, Pembaruan Hukum Pajak, PT. Raja Grafindo Persada, Jakarta.

Keputusan Majelis Madya Desa

Pakraman Kota Denpasar, Nomor 14/12SK/MMDP/VII/2014. 